\title{
Comparative Analysis of the Financial Situation in the Oil and Gas Industry in Russia and China in the Context of the COVID-19 Pandemic
}

\author{
Maria Petrovskaya $^{1}$, Xiaowei Ding $^{1 *}$ \\ ${ }^{1}$ Peoples' Friendship University of Russia, Russia \\ *Email: 491775293@qq.com
}

\begin{abstract}
With the novel coronavirus (COVID-19) wreaking havoc around the world in 2020. It led to a heavy blow to the performance of representative enterprises in the energy, aviation and other industries. Resulting in a linkage effect that led to a sharp reduction in the demand for oil and gas resources, which is the lifeblood of industrial development, and more significant uncertainty in enterprise operations. In this paper. The financial statements of CNPC and LUKOIL for the first half of 2020 are the research subjects, descriptive and comparative analysis methods are used to compare and evaluate the financial situation of the enterprises. And from this, we speculate on the financial status of the Russian and Chinese oil and gas industry. To cope with the global economic crisis and adjust development strategies providing decision-making reference.
\end{abstract}

Keywords: COVID-19, China and Russia, Oil and gas industry, Financial situation, Comparative analysis.

\section{INTRODUCTION}

Global oil demand is expected to decline in 2020 as the impact of the novel coronavirus (COVID-19) spreads around the world, constricting travel and broader economic activity, according to the International Energy Agency's latest oil market forecast. The IEA now sees global oil demand at 99.9 million barrels a day in 2020, down around 90,000 barrels a day from 2019. This is a sharp downgrade from the IEA's forecast in February, which predicted global oil demand would grow by 825,000 barrels a day in 2020 [1]. As per Dr Fatih Birol, the IEA's Executive Director, "The novel coronavirus crisis is affecting a wide range of energy marketsincluding coal, gas and renewables but its impact on oil markets is particularly severe because it is stopping people and goods from moving around, dealing a heavy blow to demand transport fuels".

There are not many studies on the comparative analysis of the financial situation of the Chinese and Russian oil and gas industries, which focuses on the following aspects.

\subsection{The relationship between international oil price fluctuation and macroeconomic}

The positive role of economic policy is well recognised by Gertler and Watson (1997). They believed that appropriate macroeconomic policies could eliminate the negative impact of oil price fluctuation on oilconsuming countries [2].

The scholars all around the world are paying more attention to the use of statistical and mathematical knowledge to research the relationship between oil price fluctuation and macroeconomic through the building of relevant models. Haltiwanger (2001) has concluded through research that the relationship between oil price fluctuation and economic activity is non-linear [3].

Chinese scholars Hongxia Gao and Yingge Xue (2009) used quantitative analysis to explore the impact of oil price fluctuation [4]. 


\subsection{The impact of the financial crisis on the Russian and Chinese oil industries}

Chinese scholars Lianyong Feng and Yue Wang consider that during the 2008 financial crisis, the Russian oil industry faced a shortage of investment. Investment in large oil, gas and petrochemical projects in Russia mostly relies on transnational financing. In the context of the deepening international financial crisis, there are difficulties in repaying debts and the danger of the outflow of investment funds [5].

Junmei Liu (2015) uses industry data on Russia's domestic oil industry, manufacturing and light industry to measure the specific impact of falling oil prices. The study shows that falling oil prices also have a positive impact on Russia's economic growth, in that they inhibit the expansion of the oil industry but promote the development of domestic machine manufacturing and light industry [6].

Jun Mi and Yanjun Liu (2016) analyse the impact shocks of international oil price volatility on the Russian financial system through an in-depth study. It is considered that Russia's rouble exchange rate tends to volatility; rouble exchange rate follows the oil price to a large extent; frequent fluctuations in the oil price can therefore cause extreme rouble exchange rate instability, making its domestic financial markets highly destabilised [7].

\subsection{Studies of financial data analysis of the oil industry}

Yakupov B.T. (2018) wrote that Russia's oil and gas industry is currently in good condition, especially concerning economic indicators of development. Still, in financial terms, the crisis in 2014 has slightly worsened the situation of the industry. Based on this analysis, the industry remains one of the most attractive areas for investment in the Russian economy [8].

Chaldaeva L.A., Chinaeva T.I. (2020) on the example of organisations "IDELOIL" JSC and "Nedra-K" LLC carried out a comparative analysis of financial indicators, proposed and justified directions to increase the gross profit and gross margin, to reduce costs and increase income. It was noted that the oil production industry in Russia depends on political and economic factors. Therefore, it is necessary to regularly analyse the activities of organisations in this industry to identify miscalculations, low-active functioning systems, etc., to more effectively operate the industry [9].

According to PWC's "Global M\&A Industry Trends in Energy, Utilities \& Resource" report, the energy, utilities and resources industry has been significantly impacted by the novel coronavirus (COVID-19), as shown in figure 1 .
As shown in figure 1 , the average transaction value decreased from \$288 million in 2018 to \$201 million in 2019 and reached only $\$ 95$ million in the first half of 2020. Based on the situation of the epidemic, the transaction value in 2020 is expected to be the lowest value in the last 10 years.

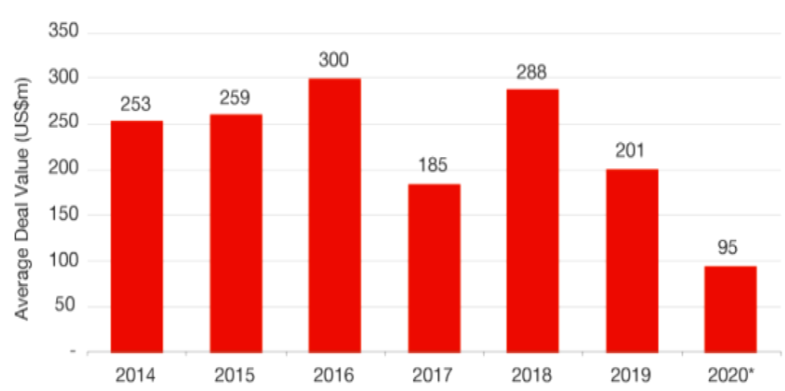

Figure 1 Global Energy, Utilities \& Resources Average Deal Values.

According to figure 2, the number of global deals has been declining year on year since peaking at 5,500 in 2017. 2020 is expected to be the lowest in the last 10 years. In the first half of 2020, the oil and gas industry has the weakest growth trend, accounting for only $60 \%$ of the 2015 deal amount.

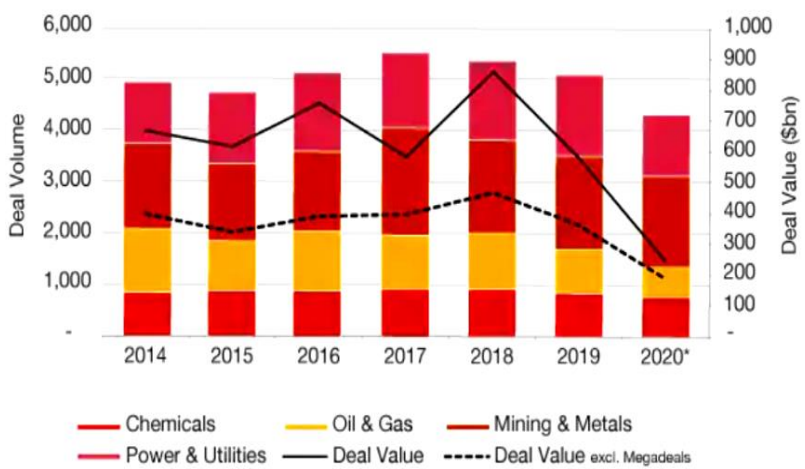

Source: Refinitiv, Dealogic and PwC analysis

Figure 2 Global Energy, Utilities and Resources Deal Volumes and Values.

By analysing the amount and number of transactions in the global energy industry in the first half of 2020, the novel coronavirus epidemic has had the biggest shock on the oil and gas industry. This research is significant since China is the world's largest crude oil importer and Russia is the world's second-largest oil producer, the comparative analysis of the financial situation of the Chinese and Russian oil and gas industries.

\section{PROFILE OF CNPC AND LUKOIL}

CNPC is one of the major suppliers and contractors in the oil and gas industry in the world. LUKOIL is Russia's largest oil company with multiple subsidiaries, controlling $19 \%$ of Russian oil production. Therefore, this paper selected CNPC and LUKOIL as the research 
subjects to evaluate and forecast the financial situation by analysing financial indicators.

The stock price fluctuations of listed companies are the most direct reflection of the macroeconomy, the analysis of CNPC and LUKOIL stock price fluctuations indirectly speculate on the current development of the industry.

As per figure 3, from January to April 2020, the price of Petro China's A-shares fell, a cumulative decrease of $22.74 \%$. The share price reached its lowest value in April. However, there was a rebound, but still maintained not more than 3.000 in May-June, the total market value of over 250 billion yuan evaporated. At the same time, according to CNPC disclosure of the annual report for the first half of 2020, the first-half loss is 29.98 billion yuan, the same period last year net profit was 28.423 billion yuan. In the last 10 years, the first half of 2020 became the worst half-year report performance.

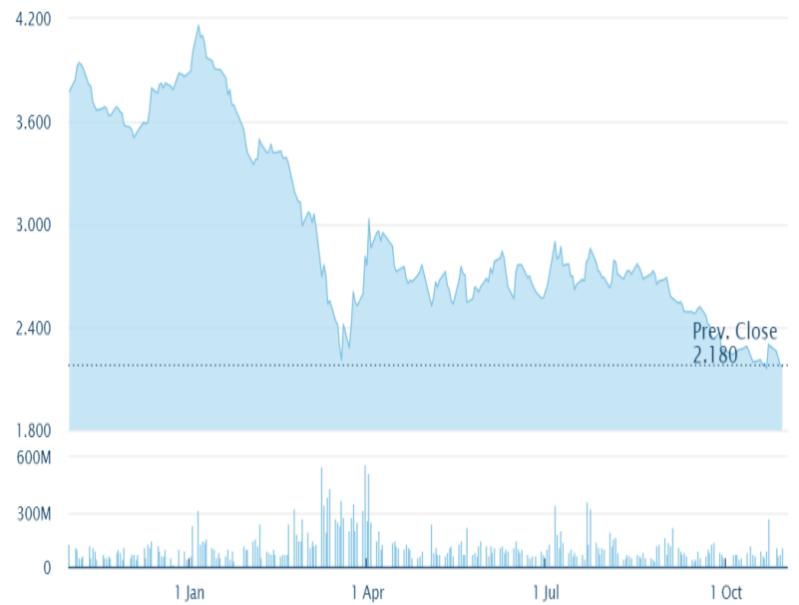

Source: Hong Kong Exchanges and Clearing Limited

Figure 3 Stock Information of PetroChina in 2020.

The MOEX Russia Index, formerly MICEX Index, is the primary rouble-denominated benchmark of the Russian stock market.

According to trading on a contract for difference (CFD) that tracks this benchmark index from Russia, the MOEX Russia Index decreased by 212 points or $6.90 \%$ since the beginning of 2020 (refer figure 4). As per Trading Economics global macro models and analysts' expectations, the MOEX Russia Index is expected to trade at 2733.20 points by the end of this quarter. Looking forward, we estimate it to trade at 2579.67 in 12 months [10].

As shown in figure 5, the MSCI Oil\&Gas Index has been declining since the outbreak of the novel coronavirus (COVID-19), and although it has rebounded since reaching its trough in early May, it is still below 20.00. Russia's oil majors: LUKOIL (MOEX), Gazprom (MOEX), Surgutneftegas (MOEX), ROSN (GDR) stock index and the MSCI Oil\&Gas index are in the same trend, indicating that the Russian oil and gas industry is currently in a severe recession situation. Therefore, we can conclude that all data indicate that the development of the Russian oil and gas industry is consistent with the development of the domestic economy. The full-scale recession in the domestic economy has led to the oil and gas industry being in a difficult situation, from which it will not be able to recover in a short time.

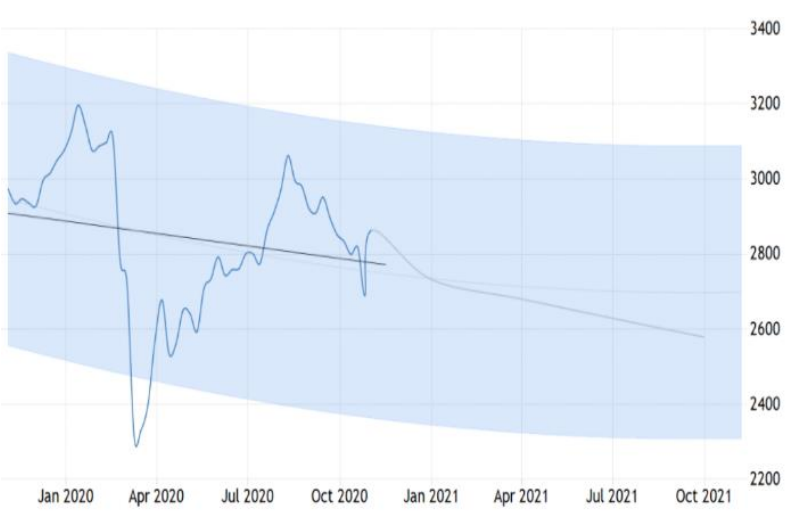

Source: Trading Economics.com

Figure 4 MOEX Russia Index Forecast.

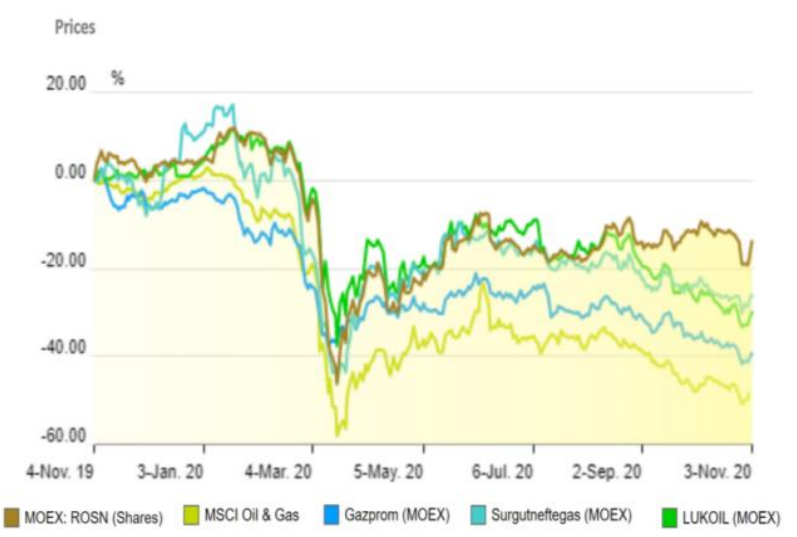

Source: Moscow Exchange

Figure 5 Shares and MOEX.

\section{FINANCIAL ANALYSIS OF CNPC AND LUKOIL}

In this paper, we used DuPont analysis, EVA financial evaluation method and Z-Score model to analyse the financial data from the aspects of profitability, operating capacity, repayment capacity, bankruptcy risk assessment, etc. At the same time, we combined statistical methods and subjective judgment to predict the future financial situation of the enterprise. We formulated practical and feasible long and short risk control strategies to reduce or even eliminate the risks. Thus, the enterprise can develop healthily and permanently.

Due to the differences in accounting methods between Russia and China and to provide a more accurate 
Table 1. Profitability indicators of CNPC and LUKOIL

\begin{tabular}{|c|c|c|c|c|c|c|}
\hline \multirow[b]{2}{*}{ Indicators } & \multicolumn{3}{|c|}{ CNPC(\%) } & \multicolumn{3}{|c|}{ LUKOIL(\%) } \\
\hline & $\begin{array}{l}\text { First half } \\
\text { (2019) }\end{array}$ & First half (2020) & $\begin{array}{c}\text { Changes over } \\
\text { the same } \\
\text { period }\end{array}$ & $\begin{array}{l}\text { First half } \\
\text { (2019) }\end{array}$ & First half (2020) & $\begin{array}{c}\text { Changes over the } \\
\text { same period }\end{array}$ \\
\hline ROE & 2.32 & -2.52 & -4.84 & 8.53 & -1.63 & -10.16 \\
\hline ROA & 1.43 & -0.87 & -2.30 & 5.60 & -1.08 & -6.68 \\
\hline Net profit margin & 3.27 & -2.51 & -5.78 & 8.31 & -2.44 & -10.75 \\
\hline
\end{tabular}

Resource: From Financial Statements of CNPC and LUKOIL

comparative analysis of the financial situation, IFRS are used in this paper.

\subsection{Profitability analysis of CNPC and LUKOIL}

From table 1, we can observe that both CNPC and LUKOIL's first-half profit levels have significantly declined, and both have negative growth trends compared to the same period. Since the outbreak of novel coronavirus first occurred in China in February and continued up to June, CNPC's stock plunged in the first half of the year, and its market capitalisation severely shrank, with ROE down $4.84 \%$ compared to the same period, which is the lowest value for CNPC in the last 10 years. Due to the enormous demand for oil in the international market in 2019, LUKOIL's net profit margin is as high as $8 \%$, far higher than CNPC's 3\%, indicate that LUKOIL's products are more competitive in the market and the profit level remains at around $8 \%$. Because the first quarter was not affected by the epidemic, LUKOIL's ROE declined less than CNPC in the first half of 2020. Still, the reduction in profitability levels was much larger than CNPC's by more than $10 \%$ over the same period.

\subsection{Operating capacity analysis of CNPC and LUKOIL}

As shown in table 2, CNPC's operating capacity showed a downward trend compared to the same period.
In contrast, LUKOIL showed a slight increase in asset turnover ratio and inventory turnover ratio. Although affected by the novel coronavirus (COVID-19), CNPC's inventory turnover ratio increased by 1.84 compared to the same period. The reason is that after the pandemic, the domestic industrial manufacturing resumes work. The rebound in oil demand making increased the inventory turnover ratio, the number of days of turnover decreased by 17 days, but because of the pandemic impact on the economy is enormous, economic recovery will take time. Thus, the receivable turnover ratio decreased by 1.6 compared to the same period.

\subsection{Repayment capacity analysis of CNPC and LUKOIL}

As shown in Table 3, CNPC's short-term debt service indexes are all lower than the standard level, indicating that in the first half of 2020, because of novel coronavirus (COVID-19) impact. Hence, the net loss is significant and realisation capability of current assets is not strong, weaker short-term repayment capacity compared to LUKOIL. CNPC's debt asset ratio of 0.48 is at an optimal level, while LUKOIL's debt asset ratio of 0.34 indicates a smaller proportion of assets provided by creditors. CNPC's Debt Service Coverage Ratio is higher than LUKOIL's, indicating strong long-term repayment capacity.

Table 2. Operating capacity indicators of CNPC and LUKOIL

\begin{tabular}{|l|c|c|c|c|c|c|}
\hline \multirow{2}{*}{\multicolumn{1}{|c|}{ Indicators }} & \multicolumn{4}{|c|}{ CNPC } & \multicolumn{3}{c|}{ LUKOIL } \\
\cline { 2 - 7 } & First half & First half & Changes over the \\
$(2020)$ & $\begin{array}{c}\text { First half } \\
\text { same period } \\
(2019)\end{array}$ & $\begin{array}{c}\text { First half } \\
(2020)\end{array}$ & $\begin{array}{c}\text { Changes over the } \\
\text { same period }\end{array}$ \\
\hline Asset turnover ratio & 0.44 & 0.39 & -0.05 & 0.44 & 0.67 & 0.23 \\
\hline Inventory turnover ratio & 5.39 & 7.23 & 1.84 & 0.60 & 0.54 & -0.06 \\
\hline Receivables turnover ratio & 16.22 & 14.62 & -1.6 & 7.96 & 7.98 & 0.02 \\
\hline
\end{tabular}

Resource: From Financial Statements of CNPC and LUKOIL 
Table 3. Repayment capacity indicators of CNPC and LUKOIL

\begin{tabular}{|c|c|c|c|}
\hline Indicators & Normal Restrictions & CNPC & LUKOIL \\
\hline Current Ratio & $1-2$ & 0.71 & 1.33 \\
\hline Quick Ratio & Minimum 0.5 & 0.45 & 1.20 \\
\hline Cash ratio & Minimum 0.2 & 0.17 & 0.30 \\
\hline Debt Asset ratio & $0.4-0.6$ & 0.48 & 0.34 \\
\hline Debt Service Coverage Ratio & 1 & -0.37 & -7.14 \\
\hline
\end{tabular}

Resource: From Financial Statements of CNPC and LUKOIL

\subsection{Assessment of the level of bankruptcy risk}

Analysis of the financial position of an enterprise necessarily relates to financial risk. Therefore, it's necessary to assess the level of bankruptcy risk for both companies. Due to the different economic environment in Russia and China, R-model is used for LUKOIL and $\mathrm{Z}$-SCORE model is used for CNPC.

Scholars of the Irkutsk State Academy of Economics have proposed a four-factor model for assessing the probability of bankruptcy of Russian companies:

$\mathrm{R}=8.38 \mathrm{~K} 1+\mathrm{K} 2+0.054 \mathrm{~K} 3+0.63 \mathrm{~K} 4$

$\mathrm{K} 1$ : the share of current assets in assets;

K2: ROE;

K3: Asset turnover ratio;

K4: production profitability.

If $\mathrm{R}$ is less than 0 , then the probability of bankruptcy is higher than $90 \%$, if $\mathrm{R}$ is between 0 to 0.18 , the probability of bankruptcy is $60-70 \%$, if $\mathrm{R}$ is between 0.18 to 0.32 , the probability of bankruptcy is $35-50 \%$, if $\mathrm{R}$ is between 0.32 to 0.42 , the probability of bankruptcy is 15 $20 \%$, if $\mathrm{R}$ is higher than 0.42 , the probability of bankruptcy is low [11].

Since there is no market price for illiquid shares in the Chinese stock market, the total market value of equity is calculated by multiplying the share price per share by the number of public shares. The following adjustments were made to the setting of the indicators in the Z-score model to consider the interest costs required for the calculation of EBIT [12].

$\mathrm{Z}=1.2 \mathrm{X} 1+1.4 \mathrm{X} 2+3.3 \mathrm{X} 3+0.6 \mathrm{X} 4+0.99 \mathrm{X} 5$

$\mathrm{X} 1=$ Current Capital $/$ Total Assets;

$\mathrm{X} 2$ = EBIT / Total Assets;

$\mathrm{X} 4=($ Market value of shares $*$ Total number of shares) / Total Debt;

$\mathrm{X} 5=$ Asset turnover ratio

While $\mathrm{Z}<1.8$, insolvency zone; $1.8 \leq \mathrm{Z}<2.99$, mid zone; $2.99<Z$, safety zone [13].

From table 4 , by analysing the $\mathrm{Z}$ and $\mathrm{R}$ values for 2015-2020 (the first half), the following conclusions can be made: the CNPC was in the safe zone for the past five years, except for 2019, where the Z-value of 2,96 is only 0,03 difference, so it can also be considered to be in the safe zone, and the Z-value of 2,09 for the first half of 2020 , where the losses are severe due to the pandemic, the Z-value is lower, but still in the mid-zone; LUKOIL has an R-value of more than 0,42 in the last 5 years, around 2, even if the R-value is 2,06 in the first half of 2020 , so the possibility of bankruptcy is very low.

Table 4. Assessment of the level of bankruptcy risk

\begin{tabular}{|l|c|c|c|l|}
\hline \multicolumn{1}{|c|}{ Year } & $\begin{array}{c}\text { Z-value } \\
(\text { CNPC })\end{array}$ & Judgement & $\begin{array}{c}\text { R-value } \\
\text { ( LUKOIL })\end{array}$ & \multicolumn{1}{|c|}{ Judgement } \\
\hline 2015 & 3,14 & safety & 2,23 & Probability of bankruptcy is low \\
\hline 2016 & 3,05 & safety & 2,29 & Probability of bankruptcy is low \\
\hline 2017 & 3,22 & safety & 2,35 & Probability of bankruptcy is low \\
\hline 2018 & 3,36 & safety & 2,47 & Probability of bankruptcy is low \\
\hline 2019 & 2,96 & mid & 2,51 & Probability of bankruptcy is low \\
\hline The half of 2020 & 2,09 & mid & 2,06 & Probability of bankruptcy is low \\
\hline
\end{tabular}




\section{CONCLUSION}

Overall, the effects of the novel coronavirus (COVID-19) on LUKOIL's profitability levels are more severe and far-reaching than CNPC's. The impact of novel coronavirus (COVID-19) on the operational capacity of CNPC was more severe, and on LUKOIL was less. However, CNPC's inventory is converted into cash or receivable seven times faster than LUKOIL and its capital utilisation rate is two times higher, so CNPC's operating capacity is stronger. As CNPC has been more severely affected by the novel coronavirus (COVID-19), its short-term repayment capacity is weaker than LUKOIL. Still, due to its higher level of financing, its long-term repayment capacity is stronger than LUKOIL. By analysing the $\mathrm{Z}$ and $\mathrm{R}$ values of the last 5 years, the probabilities of bankrupt about CNPC and LUKOIL are extremely low, which proves that the companies are running normally, and the safety and stability are very high.

The novel coronavirus (COVID-19) has had a significant impact on the oil and gas industry in China and Russia, disrupting the previous relationship between supply and demand. Therefore, it is necessary to reduce the dependence of economic development on energy, adjust the energy structure, increase the innovation of energy technology, optimise the product structure, improve the level of cost management, and enhance the profitability of enterprises, establish financial risk control mechanism, monitor the financial status of enterprises, and minimise the financial risk of enterprises; optimise the capital structure, clean up the non-performing assets in time, and avoid asset bubble. CNPC and LUKOIL, as large state-owned companies, can turn a crisis into an opportunity.

\section{REFERENCES}

[1] Retrieved from: https://www.iea.org.Report:Global oil demand to decline in 2020 as coronavirus weighs heavily on markets

[2] M. Gertler, M. Watson, Systematic Monetary Policy and the Effects of Oil Price Shocks. Brookings Papers on Economic Activity 1 (1997) 91-142.

[3] J. Haltiwanger, S.J. Davis Sectoral Job Creation and Destruction Response to Oil Price Changes, Journal of Monetary Economics 48 (2001) 465-512.

[4] Gao Hongxia, Xue Yingige, Analysis of international oil prices and oil company performance. Business Research 5 (2009) 172-174.

[5] Lianyong Feng, Yue Wang, Impact of the financial crisis on the Russian oil industry. Russian Central Asian \& East European Studies 2 (2009) 10-11.
[6] Liu Junmei, International oil prices and Russian economic growth. Eurasian Economy 6 (2015) 2730 .

[7] Mi Jun, Liu Yanjun, Impact of international oil price fluctuations on Russian economic growth. Russian Central Asian \& East European Studies 1 (2016) $112-123$

[8] B.T. Yakupov, Economic and Statistical Analysis of Oil and Gas Sector of the Russian Federation. Issues of student science 4(20) (2018) 161-165.

[9] L.A. Chaldaeva, T.I. Chinaeva, A.S. Bogopolsky, Analysis of financial and economic indicators characterising the activity of organisations of the oil and gas industry. Statistic and Economy 1 (2020) 69-70.

[10] Retrieved from: https://www.moex.com

[11] A.P. Romanov, Management of Economic Potential organisation, 2012, pp. 78.

[12] A.B. Novikova, M.A. Khalikov, The Z-SCORE models for predicting bankruptcy in the company of corporate sector of economics: criticism, directions for improvement. Fundamental research 2(10) (2015) 2213-2221.

[13] Retrieved from: https://wiki.mbalib.com 